Molecules, 2002, 7, 618-627

molecules

ISSN 1420-3049

http://www.mdpi.org

\title{
Synthesis of Substituted 2-Pyridyl-4-phenylquinolines
}

\section{Antonino Mamo*, Salvatore Nicoletti and N. Cam Tat}

Department of Physical and Chemical Methodologies for Engineering, Engineering Faculty, University of Catania, V.le Andrea Doria 6, I-95125 Catania, Italy. Tel. +39-95-7382756, Fax +39-95-333231.

* Author to whom correspondence should be addressed; e-mail: mamo@dmfci.ing.unict.it

Received: 21 June 2002; in revised form: 2 August 2002 / Accepted: 3 August 2002 / Published: 31 August 2002

\begin{abstract}
The acid-catalyzed condensation of $o$-aminobenzophenones with aromatic acetyl derivatives, in a basic methanol/tetrahydrofuran medium, has been used to prepare a series of substituted 2-pyridyl-4-phenylquinolines. Derivatives having two aza binding sites can act as asymmetric bidendate ligands to complex transition metals such as ruthenium, osmium or iridium. All the compounds were characterized by elemental analysis, Ei or FAB (+) MS, ${ }^{1} \mathrm{H}$ - and ${ }^{13} \mathrm{C}-\mathrm{NMR}$ spectroscopies. Complete assignments of the ${ }^{1} \mathrm{H}$ spectra were accomplished by using a combination of one- and two-dimensional NMR techniques.
\end{abstract}

Keywords: Quinoline derivatives, asymmetric bidentate aza-ligands, 2D-NMR.

\section{Introduction}

In the past few decades luminescent transition metal complexes based on polypyridine ligands, owing to their long-lived metal-to-ligand charge-transfer (MLCT) excited states, have already been used in various fields such as solar energy conversion [1], information storage [2], photocleavage of DNA [3], and oxygen sensors [4]. Although the photophysics and photochemistry of [Ru(bpy) $]_{3}^{2+}(\mathrm{bpy}$ $=2,2$ ' bipiridine) have been the subject of extensive research [1-4], few other bidentate ligands, i.e. having two aza binding sites, have been prepared and the photophysical and/or photochemical 
properties of their complexes with transition metals studied [5]. As a continuation of previous studies in this field [6], we now report the synthesis and characterization of the ligands shown in Scheme 1, with the aim of studing the photochemical properties of their complexes with transition metals such as ruthenium, osmium or iridium. Three of these asymmetric bidendate ligands $\left(\mathbf{L}_{\mathbf{2}}-\mathbf{L}_{\mathbf{4}}\right)$ are new. All the compounds were characterized by elemental analysis, EI or FAB mass, ${ }^{1} \mathrm{H}$ and ${ }^{13} \mathrm{C}$ NMR spectroscopies. Complete assignments of the ${ }^{1} \mathrm{H}$ spectra of the various compounds were accomplished by using a combination of one- and two-dimensional NMR techniques.

\section{Scheme 1}

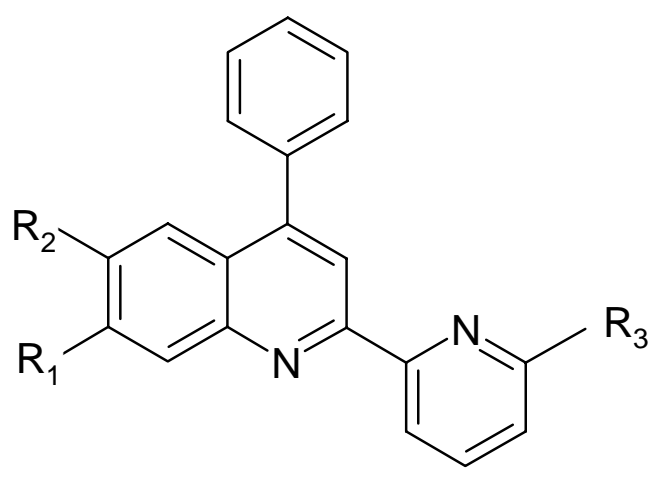

\begin{tabular}{ccccc} 
Ligands & $\mathbf{R}_{\mathbf{1}}$ & $\mathbf{R}_{\mathbf{2}}$ & $\mathbf{R}_{\mathbf{3}}$ & Initials \\
\hline $\mathbf{L}_{\mathbf{1}}$ & $\mathrm{H}$ & $\mathrm{H}$ & $\mathrm{H}$ & ph-pq \\
$\mathbf{L}_{\mathbf{2}}$ & $\mathrm{CH}_{3}$ & $\mathrm{H}$ & $\mathrm{H}$ & mph-pq \\
$\mathbf{L}_{\mathbf{3}}$ & $\mathrm{CH}_{3}$ & $\mathrm{H}$ & $\mathrm{CH}_{3}$ & mph-mpq \\
$\mathbf{L}_{\mathbf{4}}$ & $\mathrm{H}$ & $\mathrm{Br}$ & $\mathrm{CH}_{3}$ & brph-mpq
\end{tabular}

\section{Results and discussion}

The literature describes numerous different ways to prepare substituted quinoline rings: i.e., by exploiting quinoline carboxamides [7], acid-catalyzed condensation of $o$-aminobenzophenones [8] with ketones [9], sequential vinylic substitution/annelation processes [10], reactions of $\mathrm{N}$-arylnitrilium salts with acetylenes [11], cyclodehydration of $o$-vinyl anilides [12], intramolecular Wittig reactions [13], and cyclization of oximes [14]. Using $o$-isocyanostyrenes only symmetric biquinoline may be prepared [15]. Following the synthetic pathway previously used for the preparation of the unsubstituted ligand 4-phenyl-2-(2'-pyridyl)quinoline ( $\left.\mathbf{L}_{\mathbf{1}}, \mathbf{p h}-\mathbf{p q}\right)$ [16], namely the acid-catalyzed condensation of $o$ amino-benzophenone with 2- acetylpyridine derivatives, as shown in Scheme 2, we have now synthetized the ligands 4-phenyl-7-methyl-2-(2'-pyridyl)quinoline $\left(\mathbf{L}_{\mathbf{2}}, \mathbf{m p h}-\mathbf{p q}\right)$ and 4-phenyl-7methyl-2-[2'-(6'-methyl)pyridyl]-quinoline ( $\mathbf{L}_{3}, \mathbf{m p h}$-mpq). 
Scheme 2

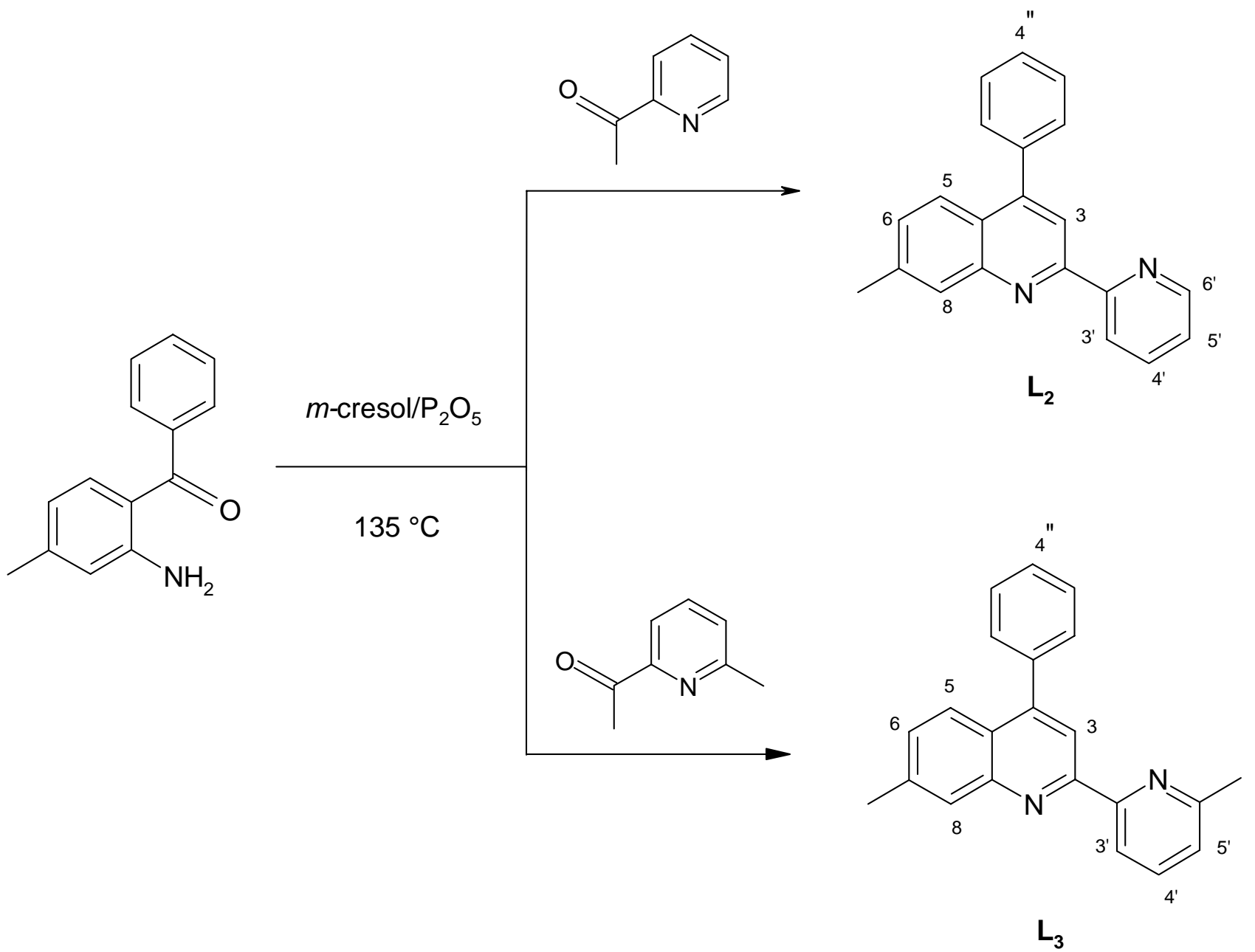

The ligand 4-phenyl-6-bromo-2-[2'-(6'-methyl)-pyridyl]quinoline ( $\mathbf{L}_{\mathbf{4}}$, $\mathbf{b r p h}$-mpq) was obtained in a three synthetic steps (Scheme 3) starting from $p$-nitrobromobenzene.

Scheme 3<smiles>O=[N+]([O-])c1ccc(Br)cc1</smiles><smiles>CO[C@H](F)CO</smiles><smiles>Brc1ccc2noc(-c3ccccc3)c2c1</smiles> 
Scheme 3 (cont.)

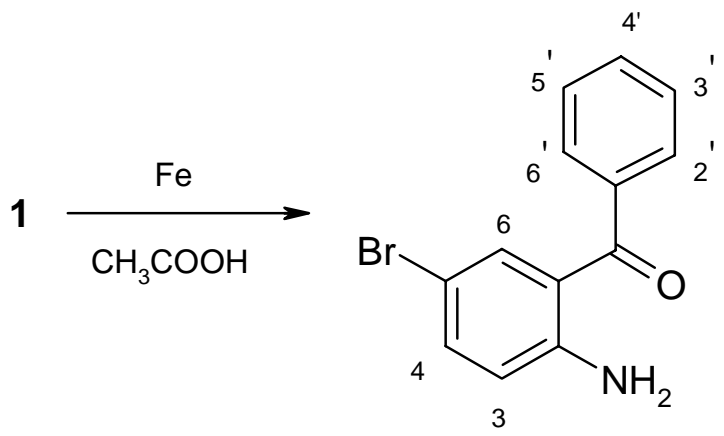

2

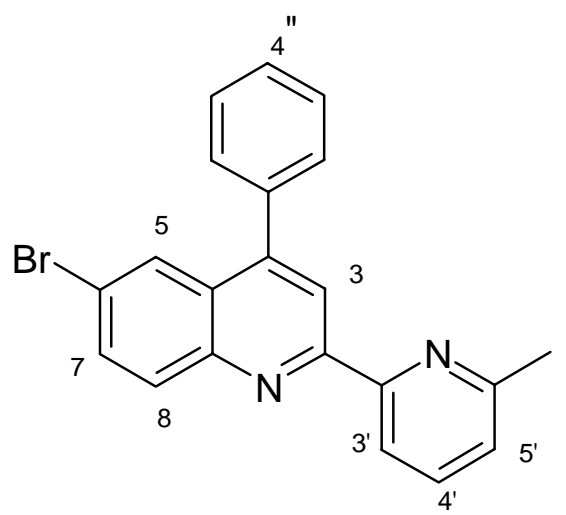

$\mathbf{L}_{4}$

2-Amino-5-bromobenzophenone (2) was obtained by condensation of $p$-nitrobromobenzene with phenylacetonitrile in a basic methanol/tetrahydrofuran medium to give 3-phenyl-5-bromo-2,1benzisoxazole (1) $(66 \%)$, which upon reductive cleavage $\left(\mathrm{Fe} / \mathrm{CH}_{3} \mathrm{COOH}\right)$ of the benzisoxazole ring was converted to the desired aminoketone $2(70 \%)$. A subsequent Friedlander reaction [17] of the $o$ aminobenzophenone 2 with 2-acetyl-6-methylpyridine, using a mixture of $m$-cresol and phosphorous pentoxide gave ligand $\mathbf{L}_{\mathbf{4}}(71 \%)$. Table I reports the results of a complete ${ }^{1} \mathrm{H}-\mathrm{NMR}$ analysis of ligands $\mathbf{L}_{\mathbf{1}}-\mathbf{L}_{4}$. Proton chemical shifts and $J(\mathrm{H}, \mathrm{H})$ values were measured at $500 \mathrm{MHz}$.

Table I. ${ }^{1} \mathrm{H}$ NMR parameters of ligands $\mathbf{L}_{\mathbf{1}}-\mathbf{L}_{\mathbf{4}}$

\begin{tabular}{|c|c|c|c|c|}
\hline \multirow{2}{*}{ Proton } & $\mathbf{L}_{\mathbf{1}}$ & $\mathbf{L}_{\mathbf{2}}$ & $\mathbf{L}_{\mathbf{3}}$ & $\mathbf{L}_{\mathbf{4}}$ \\
\hline \multirow{3}{*}{$\mathbf{3}$} & $8.53 \mathrm{~s}$ & $8.47 \mathrm{~s}$ & $8.48 \mathrm{~s}$ & $8.57 \mathrm{~s}$ \\
& & & & \\
$\mathbf{5}$ & $7.96 \mathrm{~d}$ & $7.85 \mathrm{~d}$ & $7.22 \mathrm{~d}$ & $8.06 \mathrm{~d}$ \\
& $J=8.0$ & $J=9.0$ & $J=7.5$ & $J=2.0$ \\
$\mathbf{6}$ & $7.56-7.50$ & $7.34 \mathrm{bd}$ & $7.34 \mathrm{dd}$ & - \\
& $\mathrm{m}$ & $J=6.0$ & $J=8.5,1.5$ & $7.79 \mathrm{dd}$ \\
$\mathbf{7}$ & $7.75 \mathrm{dt}$ & - & - & $J=7.0,2.0$ \\
$\mathbf{8}$ & $\mathrm{J}=7.0,1.5$ & & & $7.23 \mathrm{~d}$ \\
& $8.26 \mathrm{~d}$ & $8.05 \mathrm{bs}$ & $8.04 \mathrm{bs}$ & $J=7.5$ \\
\hline
\end{tabular}




\begin{tabular}{|c|c|c|c|c|}
\hline $3^{\prime}$ & $\begin{array}{c}8.71 \mathrm{~d} \\
J=7.5\end{array}$ & $\begin{array}{c}8.69 \mathrm{~d} \\
J=8.0\end{array}$ & $\begin{array}{l}7.83 \mathrm{~d} \\
J=8.5\end{array}$ & $\begin{array}{l}8.45 \mathrm{~d} \\
J=8.0\end{array}$ \\
\hline 4' & $\begin{array}{c}7.90 \mathrm{dt} \\
J=8.0,2.0\end{array}$ & $\begin{array}{c}7.88 \mathrm{dt} \\
J=8.0,1.5\end{array}$ & $\begin{array}{l}7.77 \mathrm{t} \\
J=7.5\end{array}$ & $\begin{array}{l}7.77 \mathrm{t} \\
J=8.0\end{array}$ \\
\hline 5 , & $\begin{array}{c}7.37 \mathrm{bt} \\
J=6.5\end{array}$ & $\begin{array}{c}7.36 \mathrm{dt} \\
J=7.5,1.5\end{array}$ & $\begin{array}{l}8.47 \mathrm{~d} \\
J=7.5\end{array}$ & $\begin{array}{l}8.10 \mathrm{~d} \\
J=8.5\end{array}$ \\
\hline 6' & $\begin{array}{c}8.74 \mathrm{~d} \\
J=4.5\end{array}$ & $\begin{array}{c}8.73 \mathrm{dd} \\
J=4.5,1.0\end{array}$ & - & - \\
\hline $\mathbf{P h}$ & $\begin{array}{c}7.62-7.50 \\
\mathrm{~m}\end{array}$ & $\begin{array}{c}7.61-7.49 \\
\mathrm{~m}\end{array}$ & $\begin{array}{c}7.61-7.50 \\
\mathrm{~m}\end{array}$ & $\begin{array}{c}7.57-7.51 \\
\mathrm{~m}\end{array}$ \\
\hline $\mathrm{Py}-\mathrm{CH}_{3}$ & - & - & $2.65 \mathrm{~s}$ & $2.64 \mathrm{~s}$ \\
\hline $\mathrm{q}-\mathrm{CH}_{3}$ & - & $2.60 \mathrm{~s}$ & $2.59 \mathrm{~s}$ & - \\
\hline
\end{tabular}

Notes: The spectra were obtained in deuterated chloroform $\left(\mathrm{CDCl}_{3}\right)$, chemical shifts in ppm, and coupling constants in Hz. Numbering pattern as shown in Schemes 2 and 3. Abbreviations used: $\mathrm{bs}=$ broad singlet, $\mathrm{s}=$ singlet, $\mathrm{d}=$ doublet, $\mathrm{dd}=$ double doublet, $\mathrm{m}=$ multiplet, $\mathrm{t}=$ triplet, $\mathrm{dt}=$ double triplet.

Assignments were aided by the use of 2D homonuclear chemical shift correlated ${ }^{1} \mathrm{H}-\mathrm{NMR}$ (COSY) [18]. As an example, Figure 1 shows the COSY-45 experiment of $\mathbf{L}_{\mathbf{1}}$ and includes as the upper and left traces the related ${ }^{1} \mathrm{H}-\mathrm{NMR}$ spectrum, both run in deuterated chloroform $\left(\mathrm{CDCl}_{3}\right)$. The $1 \mathrm{H}$ singlet at $8.53 \mathrm{ppm}$ was easily assigned by the integration ratio to the quinoline proton $\mathrm{H}^{3}$. A four-spin system is identified, through the COSY spectrum, as connecting the ${ }^{1} \mathrm{H}$ signals at 8.26, 7.96, 7.75, and 7.57-7.50 ppm. The doublet (ortho coupling) at $8.26 \mathrm{ppm}$ and the double triplet at $7.75 \mathrm{ppm}$ have been assigned to $\mathrm{H}^{8}$ and $\mathrm{H}^{7}$, respectively, by comparison with the literature ${ }^{1} \mathrm{H}$ data for $\mathbf{L}_{\mathbf{1}}$ in deuterated acetone [16].

The resonances for $\mathrm{H}^{5}$ and $\mathrm{H}^{6}$ could be assigned to the signals at 7.96 and 7.57-7.50 ppm, respectively. The ${ }^{1} \mathrm{H}$ double triplet at $7.90 \mathrm{ppm}$, diagnostic for a $\gamma$-pyridine [19], and involved in another four spin system connecting the ${ }^{1} \mathrm{H}$ signals at 8.74, 8.71, 7.90, and $7.37 \mathrm{ppm}$, was assigned to the pyridine proton $\mathrm{H}^{4^{\prime}}$. As a consequence of the meta and ortho couplings showed by $\mathrm{H}^{4^{\prime}}$, the doublets at $8.74,8.71$, and the broad triplet at $7.37 \mathrm{ppm}$, that in turn are correlated themselves, were easily assigned at $\mathrm{H}^{6^{\prime}}, \mathrm{H}^{3^{\prime}}$, and $\mathrm{H}^{5^{\prime}}$, respectively. It is worth noting that ortho, meta, and para crosspeaks are observable in the COSY-45 spectrum and can be distinguished from the number and/or the intensity of the spots. 
Figure 1: $500 \mathrm{MHz}{ }^{1} \mathrm{H} / \mathrm{H}^{1} \mathrm{COSY}-45$ spectrum of $\mathbf{L}_{\mathbf{1}}$ in deuterated chloroform. The upper and left traces are $1 \mathrm{D}$ proton spectrum of $\mathbf{L}_{\mathbf{1}}$.

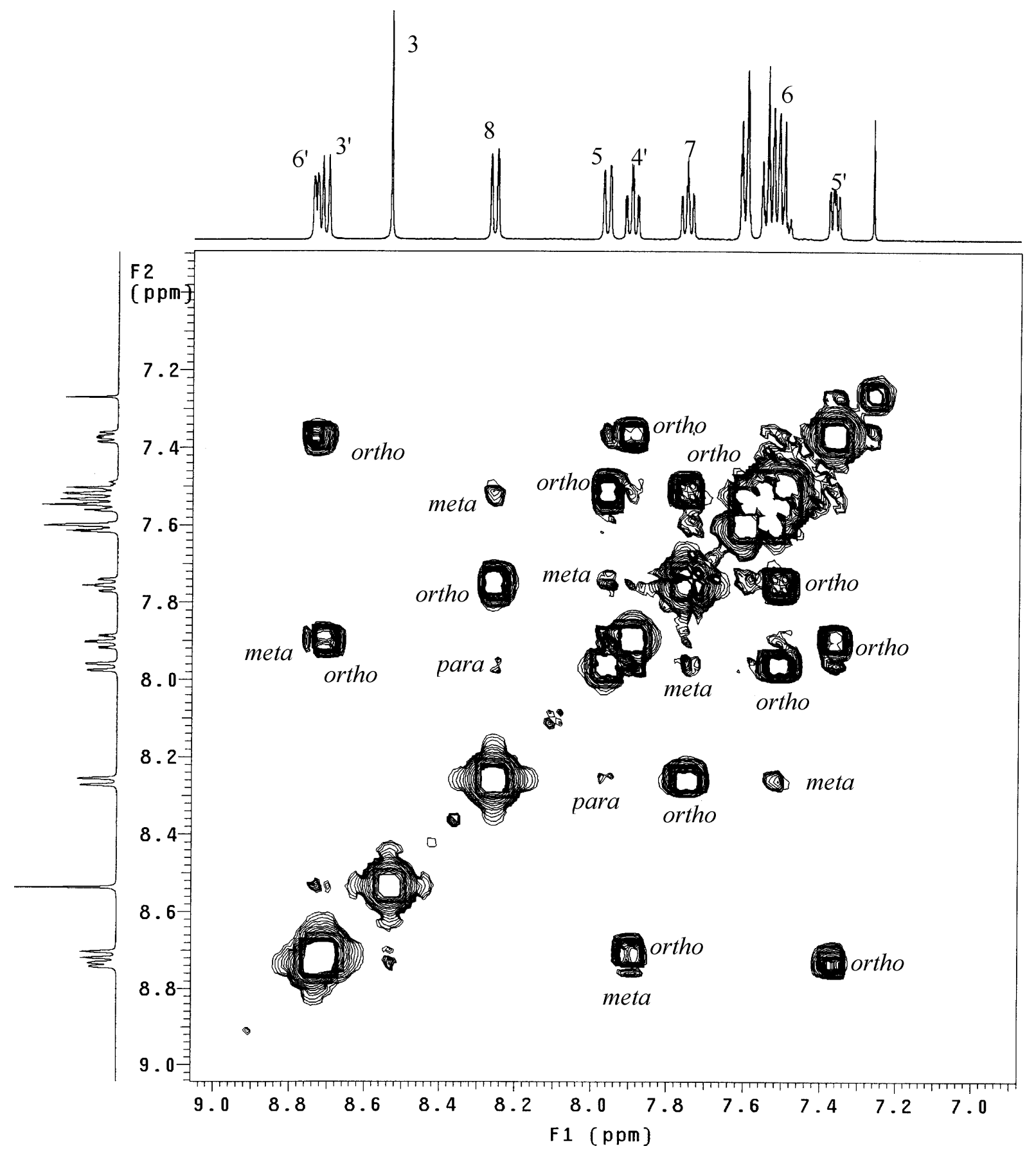

The highest downfield shift experienced by the $\mathrm{H}^{3}$ ' protons, due to deshielding by the nonbonding electrons of the nitrogen on the pyridine ring, is indicative of an anti conformation for the ligands, in agreement with the conformation considered the most probable for bipyridine [5]. According to literature data [19], confirmed by our ${ }^{1} \mathrm{H}-\mathrm{NMR}$ analyses, these uncomplexed molecules show an anti conformation (as depicted in Schemes 1 - 3) that changes to a syn one 
when they act as ligands by using the nitrogen of the pyridine and quinoline rings as binding sites. According to the inductive and/or mesomeric effects of the substituents, their introduction onto the skeleton of the N-N bidendate ligand $\mathrm{L}_{1}$ influence the upfield and/or downfield chemical shift of the nearest protons, and the reactivity of these molecules as well. The structures of ligands $\mathbf{L}_{\mathbf{1}}-\mathbf{L}_{\mathbf{4}}$ was further confirmed by their ${ }^{13} \mathrm{C}-\mathrm{NMR}$ spectra (see Table II), which displayed the expected patterns.

Table II. ${ }^{13} \mathrm{C}$ NMR parameters of ligandsf $\mathrm{L}_{1}-\mathrm{L}_{4}$

\begin{tabular}{|c|c|c|c|c|}
\hline Carbon & $\mathbf{L}_{1}$ & $\mathbf{L}_{2}$ & $\mathbf{L}_{\mathbf{3}}$ & $\mathbf{L}_{4}$ \\
\hline 2 & 156.40 & 156.54 & 155.97 & 156.35 \\
\hline 3 & 119.24 & 118.48 & 118.62 & 118.85 \\
\hline 4 & 149.23 & 149.02 & 148.88 & 148.24 \\
\hline 5 & 125.82 & 125.47 & 125.45 & 128.55 \\
\hline 6 & 128.30 & 129.03 & 128.90 & 120.80 \\
\hline 7 & 129.39 & 139.62 & 139.55 & 132.79 \\
\hline 8 & 130.21 & 129.20 & 129.16 & 131.87 \\
\hline 9 & 148.51 & 148.74 & 148.70 & 147.08 \\
\hline 10 & 126.78 & 124.78 & 124.76 & 123.80 \\
\hline 2 & 155.64 & 155.59 & 155.88 & 155.31 \\
\hline 3 ' & 121.87 & 121.78 & 118.82 & 120.11 \\
\hline $4^{\prime}$ & 136.94 & 136.87 & 137.05 & 137.11 \\
\hline 5 & 124.03 & 123.92 & 123.48 & 123.79 \\
\hline 6 & 149.17 & 149.11 & 157.90 & 158.04 \\
\hline $1 "$ & 138.40 & 138.55 & 138.74 & 137.88 \\
\hline 2"'/6" & 128.44 & 128.41 & 128.43 & 128.69 \\
\hline 3'5", & 129.67 & 129.63 & 129.64 & 129.55 \\
\hline 4" & 126.78 & 128.21 & 128.17 & 127.93 \\
\hline $\mathrm{Py}-\mathrm{CH}_{3}$ & - & - & 24.64 & 24.61 \\
\hline $\mathrm{q}-\mathrm{CH}_{3}$ & - & 21.66 & 21.67 & - \\
\hline
\end{tabular}

Notes: [a] The spectra were obtained in deuterated chloroform $\left(\mathrm{CDCl}_{3}\right)$, (chemical shifts in ppm); [b] Numbering patterns as shown in Schemes 2 and 3.

\section{Conclusions}

We report the synthesis of a series of bidentate aza chelating molecules, based on a substituted 2-pyridyl-4-phenylquinoline skeleton, that may be useful for the complexation of metal cations such as $\mathrm{Ru}$, Os, and Ir. These complexes, owing to their asymmetry, may display new and interesting photophysical properties. 


\section{Acknowledgements}

The research was financially supported by the University of Catania (PRA funds).

\section{Experimental}

\section{General}

The starting materials 2-acetylpyridine, 2-aminobenzophenone, 2-amino-4-methylbenzophenone, $p$ nitrobromobenzene, and phenylacetonitrile were purchased from Aldrich. All other chemicals were reagent grade. 6-Methyl-2-acetylpyridine [20] and the ligand 4-phenyl-2-(2'-pyridyl)pyridine $\left(\mathbf{L}_{\mathbf{1}}\right)$ [16], were prepared as described in the literature. All reactions were performed under an inert atmosphere of nitrogen except when otherwise stated and the solvents were dried and stored under nitrogen and over $4 \AA$ molecular sieves. Melting points are uncorrected. Elemental analyses were determined by a commercial laboratory. ${ }^{1} \mathrm{H}$ - and ${ }^{13} \mathrm{C}-\mathrm{NMR}$ spectra were performed in deuterated chloroform $\left(\mathrm{CDCl}_{3}\right)$ with a Varian INOVA 500 instrument. Chemical shifts were calibrated relative to the solvent resonance considered at $7.26 \mathrm{ppm}$ for residual $\mathrm{CHCl}_{3}$ and at $77.0 \mathrm{ppm}$ for $\mathrm{CDCl}_{3}$. The analysis of the proton spectra was carried out according to the rules for the first-order splitting with the help of integral intensities. The ${ }^{13} \mathrm{C}$-NMR spectra were measured with full decoupling from the protons, and the signals were assigned with the help of SCS. The quaternary carbon atoms and $\mathrm{CH}$ groups were differentiated by means of the APT pulse sequence. Positive ion FAB mass spectra were obtained on a Kratos MS $50 \mathrm{~S}$ double-focusing mass spectrometer equipped with a standard FAB source, using 3-nitrobenzyl alcohol as a matrix. The yields, melting points and elemental analyses of the ligands synthetized are presented in Table III. The ${ }^{1} \mathrm{H}$ - and ${ }^{13} \mathrm{C}-\mathrm{NMR}$ spectra with signal assignments are given in Tables I and II, respectively.

3-phenyl-5-bromo-2,1-benzisoxazole (1): Phenylacetonitrile (1.75 g, $15 \mathrm{mmol})$ was slowly added to a vigorously stirred solution of potassium hydroxide $(17.76 \mathrm{~g}, 310 \mathrm{mmol})$ in methanol $(35 \mathrm{~mL})$ at room temperature. After dissolution was complete, $36 \mathrm{~mL}$ of a methanol/tetrahydrofuran $(2: 1 \mathrm{v} / \mathrm{v})$ solution containing $p$-nitrobromobenzene $(3.0 \mathrm{~g}, 15 \mathrm{mmol})$ was added dropwise at $0{ }^{\circ} \mathrm{C}$. The resulting dark mixture was stirred at $0{ }^{\circ} \mathrm{C}$ for 3 hours, at room temperature for 4 hours, refluxed overnight, and then poured into ice-water $(300 \mathrm{~mL})$, filtered, washed successively with cold water and methanol and recrystallized from methanol to afford compound $\mathbf{1}$ as yellow crystals; $2.22 \mathrm{~g}(66 \%)$; m.p. $112{ }^{\circ} \mathrm{C} ;{ }^{1} \mathrm{H}-$ NMR $\left(\mathrm{CDCl}_{3}\right) \delta: 8.05$ (bs, $1 \mathrm{H}$, benzisoxazole $\left.\mathrm{H}^{4}\right) ; 7.99\left(\mathrm{~d}, 2 \mathrm{H}, J=7.0 \mathrm{~Hz}\right.$, phenyl $\left.\mathrm{H}^{2} / \mathrm{H}^{6}\right), 7.58(\mathrm{~m}$, $3 \mathrm{H}$, phenyl $\mathrm{H}^{4^{\prime}}$ and $\left.\mathrm{H}^{3} / \mathrm{H}^{5^{\prime}}\right) ; 7.53\left(\mathrm{dd}, 1 \mathrm{H}, J=10.0,2.5 \mathrm{~Hz}\right.$, benzisoxazole $\left.\mathrm{H}^{6}\right) ; 7.38(\mathrm{dd}, 1 \mathrm{H}, J=10.0$, $1.5 \mathrm{~Hz}$, benzisoxazole $\left.\mathrm{H}^{7}\right)$; $\mathrm{MS}, \mathrm{m} / z 274\left(\mathrm{MH}^{+}\right)$. Anal. Calcd. for $\mathrm{C}_{13} \mathrm{H}_{8} \mathrm{BrNO}$ : C, 56.95; $\mathrm{H}, 2.92 ; \mathrm{N}$, 5.11. Found: C, 57.19; H, 3.03; N, 4.86. 
2 Amino-5-bromo-benzophenone (2): Following the procedure of Simpson and Stephenson [21], a solution, containing $0.44 \mathrm{~g}(1.6 \mathrm{mmol})$ of 1 in acetic acid $(70 \mathrm{~mL})$, was heated on a water-bath, and 1.0 $\mathrm{g}(18 \mathrm{mmol})$ of iron powder was added over 2.5 hours, during which time, $12 \mathrm{ml}$ of water was also added. The mixture was filtered while hot and then $100 \mathrm{ml}$ of water was added. The yellow precipitate was collected by filtration, washed with cold water until the water washings were clear and dried. The product was purified by column chromatography (silica; cyclohexane / ethyl acetate 9:1) followed by recrystallization from ethanol-water to afford 2 as a yellow powder; $0.31 \mathrm{~g}(70 \%)$; m.p. $105{ }^{\circ} \mathrm{C}$; ${ }^{1} \mathrm{H}-\mathrm{NMR}\left(\mathrm{CDCl}_{3}\right) \delta$ : $7.63\left(\mathrm{~d}, 2 \mathrm{H}, J=8.5 \mathrm{~Hz}\right.$, phenyl $\left.\mathrm{H}^{2} / \mathrm{H}^{6^{\prime}}\right) ; 7.55\left(\mathrm{~m}, 2 \mathrm{H}\right.$, benzene $\mathrm{H}^{6}$ and phenyl $\left.\mathrm{H}^{4}\right) ; 7.49\left(\mathrm{~d}, 2 \mathrm{H}, J=8.5 \mathrm{~Hz}\right.$, phenyl $\left.\mathrm{H}^{3} / \mathrm{H}^{5}\right) ; 7.36\left(\mathrm{dd}, 1 \mathrm{H}, J=9.0,2.0 \mathrm{~Hz}\right.$, benzene $\left.\mathrm{H}^{4}\right) ; 6.65(\mathrm{~d}, 1 \mathrm{H}, J$ $=8.5 \mathrm{~Hz}$, benzene $\mathrm{H}^{3}$ ); 6.05 (bs, $\left.2 \mathrm{H}, \mathrm{NH}_{2}\right), \mathrm{MS}, \mathrm{m} / z 276\left(\mathrm{MH}^{+}\right)$. Anal. Calcd. for $\mathrm{C}_{13} \mathrm{H}_{10} \mathrm{BrNO}$ : C, 56.54; H, 3.62; N, 5.07. Found: C, 56.28; H, 3.59; N, 4.95

The synthesis of $\mathbf{L}_{\mathbf{4}}$ is given below as a general procedure for the synthesis of ligands.

4-phenyl-6-bromo-2-(2'-(6'-methyl)-pyridyl)quinoline $\left(\mathbf{L}_{\mathbf{4}}\right)$ : A mixture of $m$-cresol $(25 \mathrm{~mL})$ and phosphorus pentoxide $(0.81 \mathrm{~g}, 5.7 \mathrm{mmol})$ was stirred at $145^{\circ} \mathrm{C}$ for 2.5 hours to afford a homogeneous solution. After cooling, 2-amino-5-bromobenzophenone (4.08 g, $15 \mathrm{mmol}$ ) and 2-acetyl-6-methylpyridine $(2.03 \mathrm{~g}, 15 \mathrm{mmol})$ were added, followed by additional $m$-cresol $(20 \mathrm{~mL})$ to rinse the powder funnel. The reaction mixture was heated at $135{ }^{\circ} \mathrm{C}$ overnight. After cooling, the dark solution was poured into ethanol $(200 \mathrm{~mL})$ containing triethylamine $(20 \mathrm{~mL})$. The resulting light grey precipitate was collected by filtration, continuosly extracted with a solution of ethanol/triethylamine for 24 hours, and recrystallized from $n$-hexane/methylene chloride to give $\mathbf{L}_{\mathbf{4}}$ as an off white powder; $3.96 \mathrm{~g}$ (71\%); m.p. $=212{ }^{\circ} \mathrm{C} ; \mathrm{MS}, \mathrm{m} / \mathrm{z} 375\left(\mathrm{MH}^{+}\right)$.

Table III. Melting points, yield and elemental analyses of ligands $\mathbf{L}_{\mathbf{1}}-\mathbf{L}_{\mathbf{4}}$

\begin{tabular}{|c|c|c|c|c|c|c|c|}
\hline \multirow[t]{2}{*}{ Ligand } & \multirow{2}{*}{$\begin{array}{c}\text { Recrystallization } \\
\text { Solvent(s) }\end{array}$} & \multirow{2}{*}{$\begin{array}{l}\text { M.p: } \\
\left({ }^{\circ} \mathbf{C}\right)\end{array}$} & \multirow{2}{*}{$\begin{array}{c}\text { Yield } \\
(\%)\end{array}$} & \multirow{2}{*}{$\begin{array}{l}\text { Formula / } \\
\text { M. w. }\end{array}$} & \multicolumn{3}{|c|}{$\begin{array}{c}\text { Elemental Analysis } \\
\text { Calculated/Found (\%) }\end{array}$} \\
\hline & & & & & $\mathbf{C}$ & $\mathbf{H}$ & $\mathbf{N}$ \\
\hline \multirow{2}{*}{$\mathbf{L}_{1}$} & \multirow{2}{*}{$\mathrm{EtOH}$} & \multirow{2}{*}{152} & \multirow{2}{*}{70} & $\mathrm{C}_{20} \mathrm{H}_{14} \mathrm{~N}_{2}$ & 85.05 & 5.00 & 9.90 \\
\hline & & & & 296.35 & 85.00 & 5.05 & 10.00 \\
\hline \multirow{2}{*}{$\mathbf{L}_{2}$} & \multirow{2}{*}{$\mathrm{EtOH} / \mathrm{CHCl}_{3}$} & \multirow{2}{*}{138} & \multirow{2}{*}{62} & $\mathrm{C}_{21} \mathrm{H}_{16} \mathrm{~N}_{2}$ & 85.10 & 5.44 & 9.45 \\
\hline & & & & 296.35 & 85.02 & 5.63 & 9.32 \\
\hline \multirow{2}{*}{$\mathbf{L}_{3}$} & \multirow{2}{*}{$\mathrm{EtOH} / \mathrm{H}_{2} \mathrm{O}$} & \multirow{2}{*}{194} & \multirow{2}{*}{60} & $\mathrm{C}_{22} \mathrm{H}_{18} \mathrm{~N}_{2}$ & 85.13 & 5.84 & 9.02 \\
\hline & & & & 310.38 & 85.11 & 5.93 & 9.12 \\
\hline \multirow{2}{*}{$\mathbf{L}_{4}$} & \multirow{2}{*}{$n-\mathrm{C}_{6} \mathrm{H}_{12} / \mathrm{CH}_{2} \mathrm{Cl}_{2}$} & \multirow{2}{*}{212} & \multirow{2}{*}{71} & $\mathrm{C}_{21} \mathrm{H}_{15} \mathrm{BrN}_{2}$ & 67.21 & 4.03 & 7.46 \\
\hline & & & & 375.26 & 67.33 & 4.34 & 7.33 \\
\hline
\end{tabular}




\section{References}

1. (a) Bignozzi, C.A.; Schoonover, J.R.; Scandola, F. Prog. Inorg. Chem., 1997, 44, 1; (b) Balzani, V.; Campagna, S.; Denti, S.; Juris, A.; Serroni, S.; Venturi, M. Acc. Chem. Res., 1998, 31, 26.

2. Lehn, J.M. Supramolecular Chemistry, VCH: Weilheim, 1995. (b) Collin, J.P.; Gavina, P.; Heitz, V.; Sauvage, J.P. Eur. J. Inorg. Chem. 1998, 1.

3. Arounaguiry, A.; Maiya, B.G. Inorg. Chem. 2000, 39, 4256

4. Di Marco, G.; Lanza, M.; Mamo, A.; Stefio, I.; Di Pietro, C.; Romeo, G.; Campagna, S. Anal. Chem. 1998, 70, 5019

5. Juris, A.; Balzani, V.; Barigeletti, F.; Campagna, S.; Belser, P.; von Zelewsky, A. Coord. Chem. Rev. 1988, 84, 85.

6. (a) Mamo, A. J. Heterocyclic. Chem., 2000, 37, 1225. (b) Mamo, A.; Stefio, I.; Parisi, M.F.; Credi, A.; Venturi, M.; Di Pietro, C.; Campagna, S. Inorg. Chem. 1997, 36, 5947. (c) Mamo, A.; Stefio, I.; Poggi, A.; Tringali, C.; Di Pietro, C.; Campagna, S. New. J. Chem. 1997, 21, 1173.

7. Dubroeucq, M.C.; Renault, C.; Le Fur, G. (Pharmuka Laboratories, Fr.), 1985, U.S. Pat. 4499094.

8. Walsh, D.A. Synthesis, 1980, 677.

9. Ubeda, J.I.; Villacampa, M.; Avendano, C. Synthesis, 1999, 8, 1335.

10. Arcadi, A.; Cacchi, S.; Fabrizi, G.; Marinelli, F.; Pace, P. Synlett. 1996, 6, 568.

11. Mahmoud, A.; Johannes, J.C.; Quanrui, W.; Atef, H.; Abd El Hamid, I. Synthesis, 1992, $9,875$.

12. Curran, D.P.; Kuo, S.C. J. Org. Chem. 1984, 49, 2063.

13. Schweizer,E.E.; Goff, S.D.; Murray, W.P. J. Org. Chem. 1977, 42, 200.

14. Goszczynshi, S.; Kucherenko, A.I. Zh. Org. Khim. 1972, 8, 2586.

15. Kobayashi, K.; Yonemori, J.; Matsunaga, A.; Kitamura, T.; Tanmatsu, M.; Morikawa, O.; Konishi, H. Heterocycles, 2001, 55, 33

16. Campagna, S.; Mamo, A.; Stille, J.K. J. Chem. Soc. Dal ton Trans. 1991, 2545

17. Riego, E. C.; Jin, X.; Thummel, R.P. J. Org. Chem. 1966, 61, 3017.

18. Aue, W. P.; Bartholdi, E.; Ernst, R. R. J. Chem. Phys. 1964, 64, 2229.

19. Finocchiaro, P.; Mamo, A.; Tringali, C., Magn. Res. Chem. 1991, 29, 1165.

20. Parks, J. E.; Wagner, B. E.; Holm, R. H. J. Organomet. Chem. 1973, 56, 53.

21. Simpson, J.; Stephenson, O. J. Chem. Soc. 1942, 353.

Sample Availability: Available from the authors.

(C) 2002 by MDPI (http://www.mdpi.org). Reproduction is permitted for noncommercial purposes. 